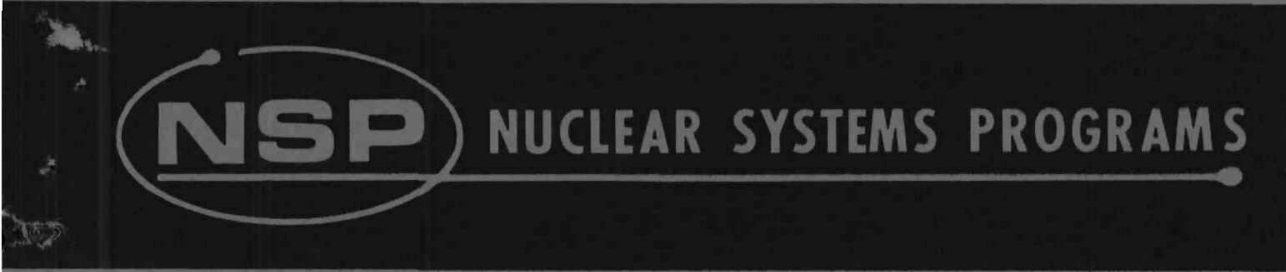

EVALUATIONS OF URANIUM MONONITRIDE CERMET FUEL

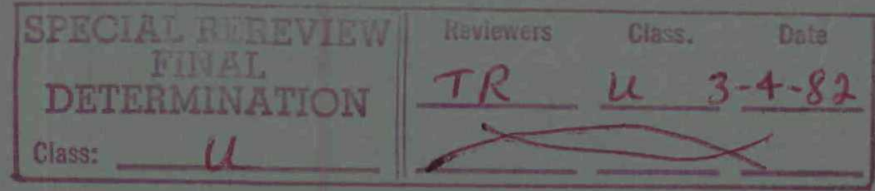

October 1968

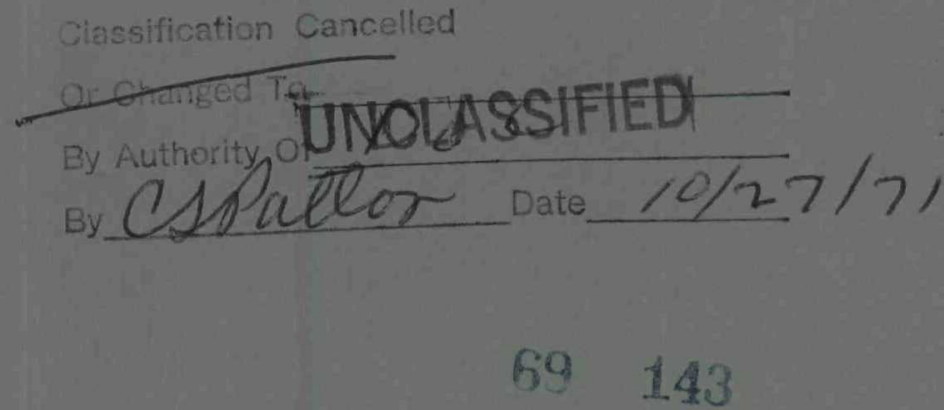

Nuclear Systems Programs Space Systems

GENERAL ELECTRIC

Missile and Space Division

Cincinnati, Ohio 45215

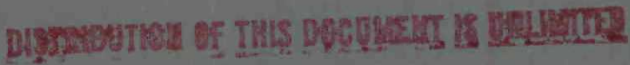

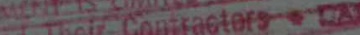

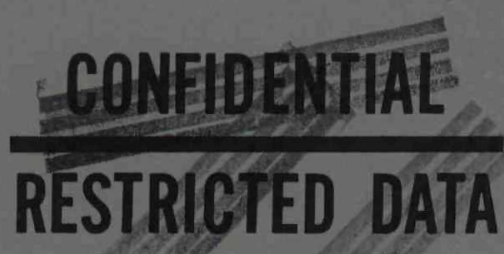

THIS DOCUMENT CONTAINS RESTRICTED DATA AS DEEINED IN THE ATOMIC ENERGY ACT OF 1954, ITS TRANSMITTAL OR THE DISCLOSURE OF UTS CONTENTS IN ANY MANNER TO AN UNAUTHORIZED PERSON IS PROHIBITED. GROUP 1

$$
\begin{aligned}
& \because \because \because \therefore \quad \therefore \cdots \because \because: \cdots: \because: \text { EXCLUDED FROM AUTOMATIC DOWNGRADING } \\
& \text { AND DECLASSIFICATION. }
\end{aligned}
$$

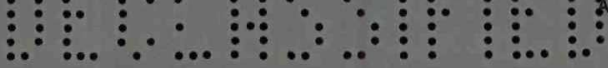




\section{DISCLAIMER}

This report was prepared as an account of work sponsored by an agency of the United States Government. Neither the United States Government nor any agency Thereof, nor any of their employees, makes any warranty, express or implied, or assumes any legal liability or responsibility for the accuracy, completeness, or usefulness of any information, apparatus, product, or process disclosed, or represents that its use would not infringe privately owned rights. Reference herein to any specific commercial product, process, or service by trade name, trademark, manufacturer, or otherwise does not necessarily constitute or imply its endorsement, recommendation, or favoring by the United States Government or any agency thereof. The views and opinions of authors expressed herein do not necessarily state or reflect those of the United States Government or any agency thereof. 


\section{DISCLAIMER}

Portions of this document may be illegible in electronic image products. Images are produced from the best available original document. 
J. F. Collins and D. L. Newsom Fuel Element Development

\section{NOTICE}

This report was prepared as an account of work This report was prepared as an account sponsored by the United Stited States Atomic Energy the United States nor the United States Atomic Enersy Commission, nor any of their employees, nor any their contractors, subcontractors, or their er assumes any makes any waxranty, express or implied, or assucy, comlegal liability or responsibility for the accuracy, completeness or usefulness of any information, apparatus, product or process disclosed, or represents that its use product or process disclely owned rights.

October 1968

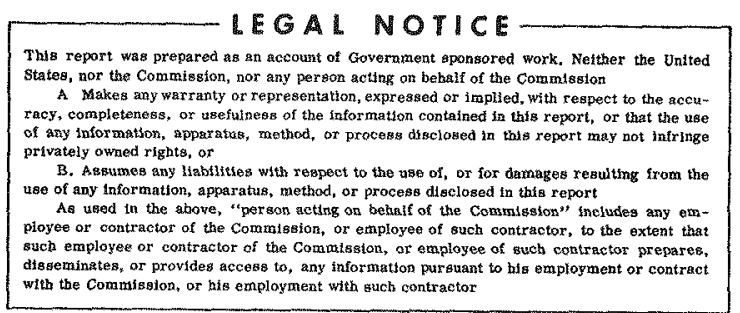

UNCLASSIEIED

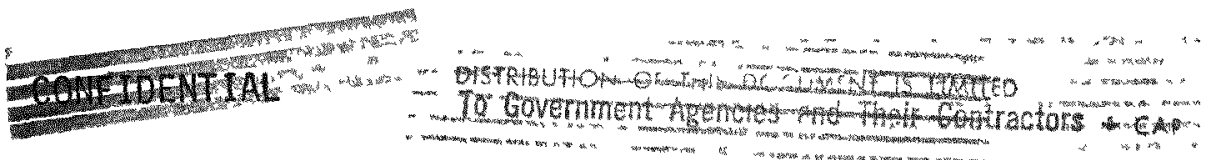




\section{DISTRIBUTION}

AEC, CAO

C. L. Karl

AEC Headquarters
A. Van Echo
C. Johnson
G. Dicker

AEC, RDT-OSR (GE-NSP)

J. F. Weissenberg

BMI-Columbus

D. Keller

5. Paprocki

NASA-Lewis Research Center

J. W. Creach

R. Migra

N. Saunders

ORNL

W. 0. Harmes

D. H. Ahmanm (2)

E. E. Hoffman

H. C. Brassfield

E. A. Kelley

V. P. Calkins

J. A. McGurty

J. F. Collins (2)

J. Moteff

P. K. Conn

D. L. Newsom

J. B. Conway

G. W. Pomeroy

R. H. Danforth

R. E. Seibert

J. Danko (2)

J. E. Van Hoomissen

R. Frank

$R$. Van Houten

R. E. Fryxell

M. A. Zipkin

E. S. Funston

Library (10)

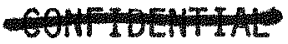




\title{
EVALUATIONS OF URANIUM MONONITRIDE CERMET FUEL
}

by J.F. Collins and D. L. Newsom

\author{
A B S TRACT
}

As a cermet fuel uranium mononitride (UN) has been recognized to offer several advantages over other fuel forms, including higher uranium content, better thermal conductivity and lower thermal expansion. Recent work at GE-NSP has demonstrated improved dimensional stability or resistance to growth under thermal cyclic test conditions for $W-U N$ and Mo-UN cermet fuel cores.

Stoichiometric UN of controlled particle size was prepared by direct nitriding of uranium metal shot resulting in oxygen contents of 500 to $800 \mathrm{ppm}$ and particle sizes of 100 to 150 microns. W-60uN and Mo-60UN cermet compacts were prepared using this fuel and sintered in pure nitrogen at $2000^{\circ} \mathrm{C} . \mathrm{Clad}$ with tungsten alloys or molybdenum, these fuel specimens were thermal cyclic tested to $1800^{\circ} \mathrm{C}$ in helium. After 60 rapid cycles the UN cermets grew less than 0.5 percent in diameter or about half the growth of $W-\mathrm{UO}_{2}$ cermets tested under the same conditions. No evidence of un instability was found.

The need for further studies of UN cermets as an alternate fuel form is discussed with the objective of qualifying UN for advanced reactor and thermionic emitter applications.

The uranium fuels of orime interest for high temperature fuel elements are $\mathrm{UO}_{2}, U C$, and $U N$. $\mathrm{UO}_{2}$ is the most commonly used fuel because of its stability and has been thoroughly evaluated as a dispersion fuel under the GE-NSP program of the past 6 years. UC has not been seriously considered as a candidate fuel for refractory metal fuel elements because of its incompatibility at high temperatures. Of the three uranium fuels, UN has the highest specific uranium content $(W-72$ vol.\% UN is equivalent to bulk $\mathrm{UO}_{2}$ ), the highest thermal conductivity, the highest resistance to deformation at elevated temperatures, and reportedly more favorable resistance to high burnup at temperature greater than $1200^{\circ} \mathrm{C}$. The compatibility of UN with $W$ is good to $2800^{\circ} \mathrm{C}$ and with Mo to at least $1800^{\circ} \mathrm{C}$. The linear thermal expansion coefficient of UN is lower and the thermal conductivity of UN is considerably

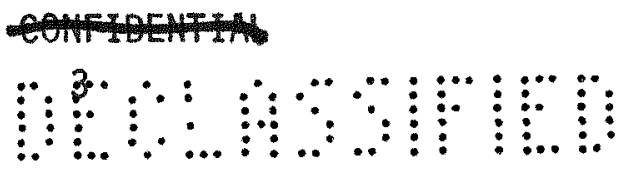




\section{(4:}

(1)

greater than that of $\mathrm{UO}_{2}$. The comparative properties of UN and $\mathrm{UO}_{2}$ are given in Table 1. These data suggest that cermets of $W-U N$ and Mo-UN should have properties superior to cermets containing $\mathrm{UO}_{2}$, assuming stoichiometric fuel is maintained in each case.

\section{TABLE 1}

COMPARATIVE PROPERTIES OF UN AND UO2

$\begin{array}{lcc} & \frac{U N}{U} & \frac{\mathrm{UO}}{2} \\ \text { Uranium Density, } \mathrm{g} / \mathrm{cm}^{3} & 13.6 & 9.6 \\ \text { X-ray Density, } \mathrm{g} / \mathrm{cm}^{3} & 14.32 & 10.97 \\ \text { Melting Point, }{ }^{\circ} \mathrm{C} & 2850 & 2790 \\ \text { Thermal Expansion Coef., } 10-6 /{ }^{\circ} \mathrm{C} & 8.61 & 10.52 \\ \text { Thermal Conductivity, watts } / \mathrm{cm}-{ }^{\circ} \mathrm{C} & 0.26 & 0.06\end{array}$

Comparative data for thermal expansion of cermets containing UN and $\mathrm{UO}_{2}$ are given in Table 2 and for thermal conductivity in Table 3.

Although considerable data have been reported on UN as a bulk fuel, the development of UN as a dispersion fuel in cermet cores has received little attention. Investigations of UN as alternate fuel for refractory metal fuel elements have been conducted during the past year at GE-NSP and have produced encouraging results. The objectives of this program were to develop UN fuel and $W$-UN cermets along the same lines as the technological development of $\mathrm{W}_{-} \mathrm{UO}_{2}$ in past work at GE-NMPO.

The work on UN at GE-NSP has included the preparation of high-purity UN of controlled particle size, the development of blending and sintering procedures for $W$-UN and Mo-UN cermet cores containing stoichiometric UN, the cladding of such cores with refractory metals ( $W$, Mo), and evaluations of the dimensional stability of UN cermet fuel elements under thermal cyclic test conditions.

PREPARATION OF STOICIIOMETRIC UN AS COARSE PARTICLES The commercially available form of UII is submicron pouder produced from uranium hydride. This powder has a normally high oxygen or $\mathrm{UO}_{2}$ content, tends to be pyrophoric, and must be processed in an inert atmosphere. For dispersion fuel cores spherical particles of un are needed that can be dispersed in a continuous metal matrix or possibly coated with tungsten by chemical vapor deposition (CVD).

Efforts to agglomerate UN powder by the same procedures used at GE-NSP for preparing $\mathrm{UO}_{2}$ agglomerates proved unsuccessful because of the high resistance of UN particles to deformation in cold pressing and consequent lack of strength in the green agglomerates. 
TABLE 2

MEAN THERMAL EXPANSION COEFFICIENTS FOR CERMET FUELS

\begin{tabular}{|c|c|c|c|c|}
\hline $\begin{array}{l}\text { Composition, } \\
\text { v01.\% } \\
\end{array}$ & $\begin{array}{l}\text { Density, } \\
\text { \& Theor. }\end{array}$ & $\begin{array}{l}\text { Temp. Range, } \\
{ }^{\circ} \mathrm{C} \\
\end{array}$ & $\begin{array}{l}\text { Linear Expan. Coef., } \\
10^{-6} \text { per }{ }^{\circ} \mathrm{C} \\
\end{array}$ & Refer. \\
\hline UN & 97 & $25-960$ & 8.61 & 2,3 \\
\hline $\mathrm{UO}_{2}$ & - & $25-960$ & $10.52-10.58$ & $2,3,6$ \\
\hline !! & 97 & $25-960$ & 4.48 & 2,3 \\
\hline Mo-80UN & 91 & $20-950$ & $9.1-9.5$ & 5 \\
\hline $\mathrm{Mo}-80 \mathrm{UO}_{2}$ & 94 & $20-950$ & $8.8-9.2$ & 4 \\
\hline$W-57 \mathrm{UO}_{2}$ & 99 & $25-960$ & $7.3-7.5$ & 2,3 \\
\hline
\end{tabular}

TABLE 3

THERMAL CONDUCTIVITY OF CERMET FUELS

\begin{tabular}{|c|c|c|c|c|}
\hline $\begin{array}{l}\text { Composition, } \\
\text { vol. \% } \\
\end{array}$ & $\begin{array}{l}\text { Density } \\
\text { \% Theor. }\end{array}$ & $\begin{array}{c}\text { Temp. Range, } \\
{ }^{\circ} \mathrm{C} \\
\end{array}$ & $\begin{array}{l}\text { Thermal Conduct., } \\
\text { watt } / \mathrm{cm}-{ }^{\circ} \mathrm{C}\end{array}$ & Refer. \\
\hline$U N^{a}$ & $\overline{92-96}$ & $900-1650$ & $0.19-0.26$ & 9 \\
\hline $\mathrm{UO}_{2}$ & - & $900-2400$ & $0.05-0.06$ & 7 \\
\hline $\mathrm{UO}_{2}$ & - & $100-800$ & $0.078-0.032$ & 4 \\
\hline Mo-80un & 91 & $200-1000$ & $0.57-0.63$ & 8,10 \\
\hline $\mathrm{Mo}-80 \mathrm{UO}_{2}$ & - & $100-900$ & $0.21-0.26$ & 4 \\
\hline $\mathrm{W}-60 \mathrm{UO}_{2}$ & - & $800-2000$ & $0.31-0.22$ & 7 \\
\hline$w$ & - & $800-1800$ & $1.2-1.0$ & 16 \\
\hline Mo & - & $800-1800$ & $1.0-0.85$ & 17 \\
\hline
\end{tabular}

at pressed powder, $900-1700 \mathrm{ppm} 0_{2}+\mathrm{C}$. 


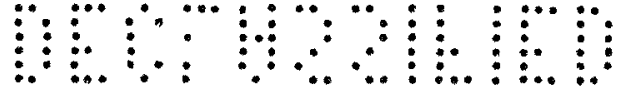

An improved process for preparing UN spherical particles has been developed at GE-MSP, using uranium metal shot in a direct nitriding procedure. The principle, as described in a US-AEC Patent, 14 is one of nitriding the surface of $U$ metal spheres below the melting point of $U\left(1733^{\circ} \mathrm{C}\right)$, then raising the temperature gradually past the melting point to completely nitride the remainder of the $U$ in the particles at temperatures above the melting point of the metal. Subsequent heating to $2200^{\circ} \mathrm{C}$ in nitrogen and cooling in vacuum adjusts the nitrogen content to stoichiometric UN.

Normal uranium metal shot of high purity was obtained in the size range of 80 to 140 mesh (100 to 175 micron diameter) from AEC-HLO, Fernald, Ohio. The shot was treated in nitric acid to remove the surface oxide. Then small batches contained in tungsten crucibles were outgassed at $800^{\circ} \mathrm{C}$ in vacuum and cooled to black heat. Pure nitrogen was introduced under 1.3 atmospheres pressure and the furnace temperature slowly increased to $1000^{\circ} \mathrm{C}$ to nitride the surface of the $U$ shot, then to $1350^{\circ} \mathrm{C}$ to complete the nitriding process. The furnace was then evacuated and the UN cooled in vacuum to room temperature. The resulting material was rich in nitrogen with considerable amount of $U_{2} \mathrm{H}_{3}$. These small lots of UN particles were combined in larger batches, and heated to $2200^{\circ} \mathrm{C}$ under nitrogen pressure to adjust the stoichiometric composition.

The analysis of two lots of UN recently prepared showed $94.49 \%$ and $94.53 \% \mathrm{U}$ (vs $94.44 \% \mathrm{U}$ in stoichiometric UN) and 820 and $680 \mathrm{ppm}$ oxygen, respectively. Analys is by XRD showed a major phase of UN with a trace of $\mathrm{UO}_{2+x}$, but no $U_{2} \mathrm{~N}_{3}$. Photomicrographs of the starting $U$ metal shot and the UN particles produced from the shot are shown in Figure 1. These coarse particles of UN are stable in air at room temperature and, unlike the fine UN powder, can be handled without need for protective atmospheres.

This direct nitriding process provides a relatively simple method of preparing coarse UN particles of low oxygen content. It is dependent, however, on the availability of $U$ metal shot, both normal and enriched, in the range of particle sizes required for cermet fabrication (100 to 325 mesh). Any extensive research program on uN fuel should include the development of $U$ metal shot produced to specifications for particle size and oxygen content.

PREPARATION OF CERMET CORES OF W-UN AND MD-UN

The sintering procedures developed at GE-NSP in the past were based on the use of agglomerated $\mathrm{UO}_{2}$ to abtain high density in $\mathrm{W}-\mathrm{UO}_{2}$ cermet cores. It was recognized early that compacts containing hard, dense fuel particles could not be sintered readily to high density. The same problem exists for $W$-UN compacts containing coarse, hard particles of UN fuel. To take advantage of the spherical particles of UN produced from $U$ metal shot, however, a lower sintered density was accepted for H-UN, and the core compacts were subsequently densified by hot-gas isostatic pressing (autoclaving).

Since it had been shown that a continuous metal matrix (optimum dispersion of fuel) could be obtained by the GE-NSP Camcoat process, 15 blending of W-UN and Mo-UN was performed by that method. The UN

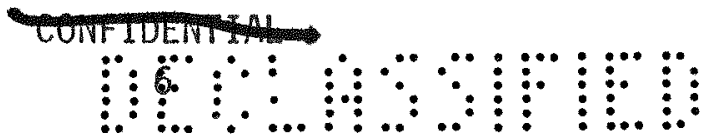




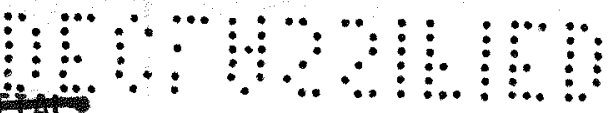

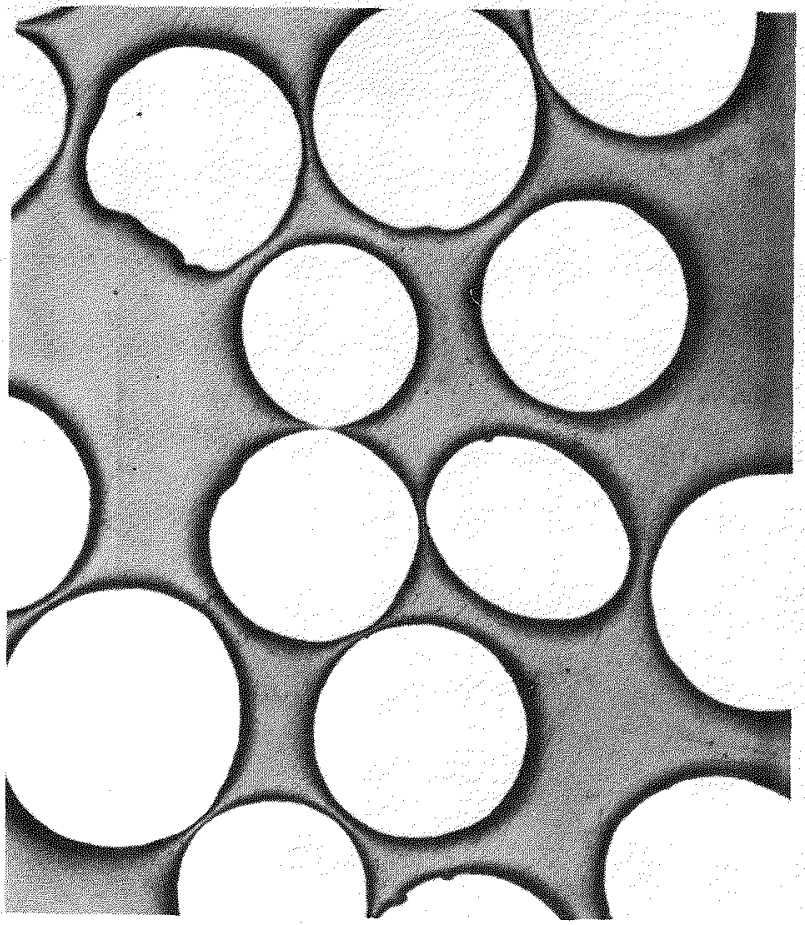

Neg. 9239

Uranium Metal Shot

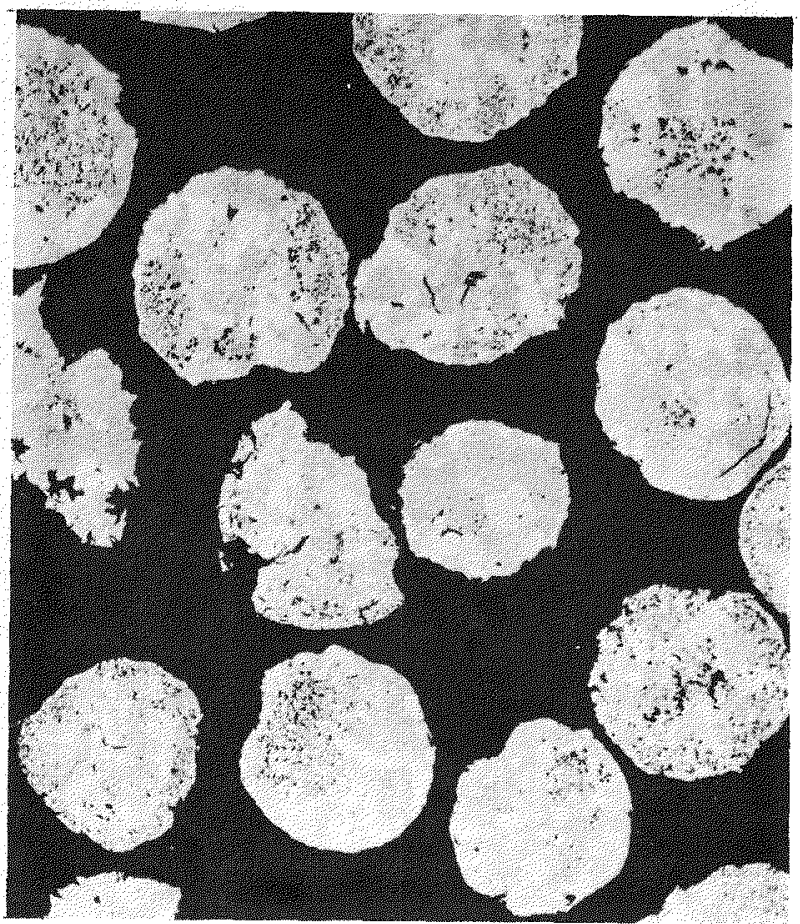

Neg. 9240

UN Fuel Particles Prepared from U lletal Shot

Figure 1 - High-purity uranium mononitride particles prepared by direct nitriding of $U$ metal shot. (Mag. 100X)

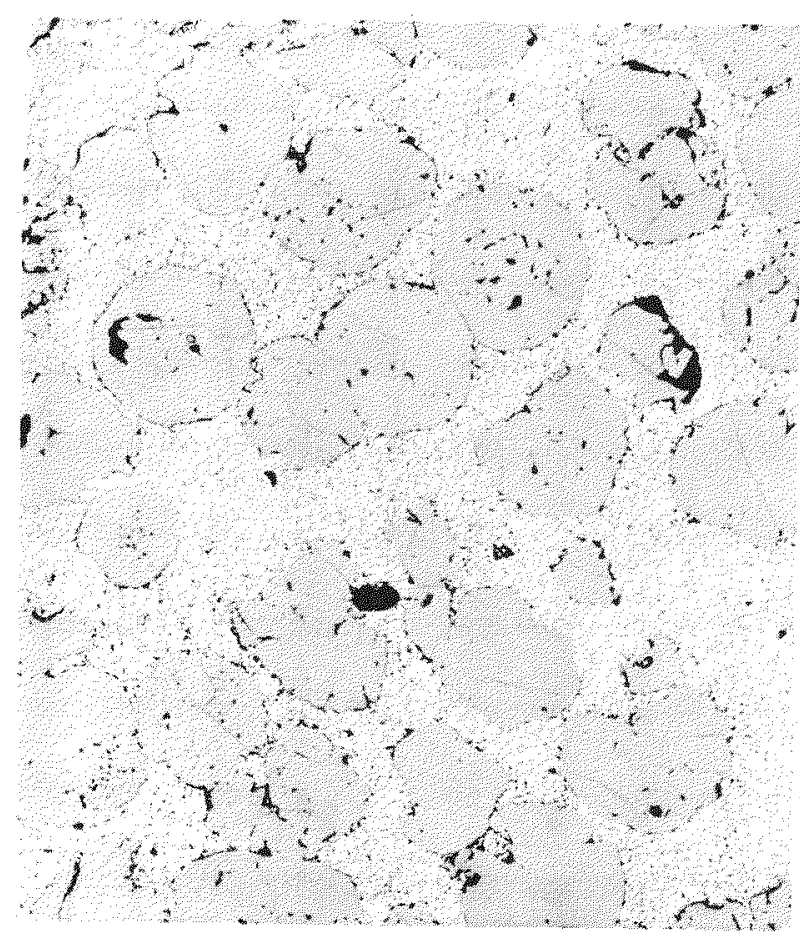

Neg. 10674

W-60UN

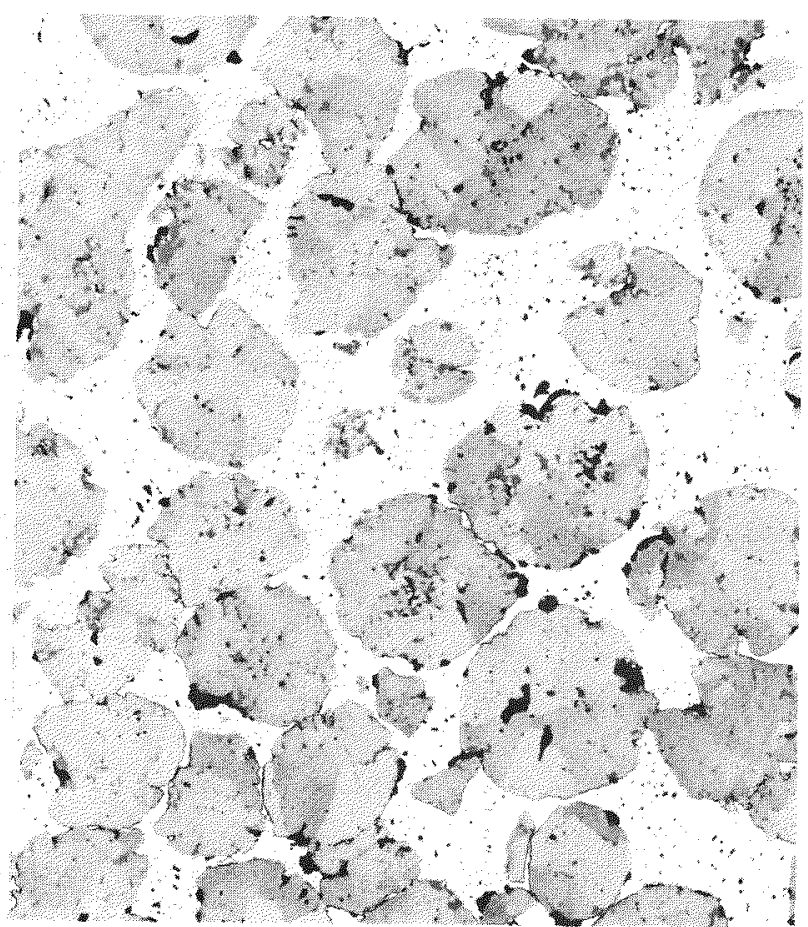

Neg. 10675

MO-60UN

Figure 2 - Microstructures of cermet cores of W-UN and MO-UN prepared with UN particles of 150 micron diameter, sintered in nitrogen at $2000^{\circ} \mathrm{C}$ and consolidated by hot-gas isopressing to 95-97\% of theoretical density. (Mag. 100X) 


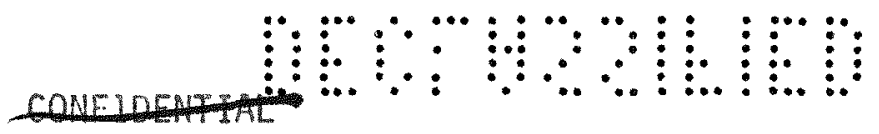

particles of $-80 /+140$ mesh size (100-175 micron) were coated with submicron powder of tungsten or molybdenum by the Camcoat process and cold pressed at 30,000 to 50,000 psi to form rod-shaped compacts of 0.6 inch diameter. Based on preliminary studies of UM stability when sintered in various environments and to maintain fuel stoichiometry while sintering $W-60 U N$ or Mo-60UN compacts, the following procedure was used:

1. Heat in vacuum slowly to $1400^{\circ} \mathrm{C}$.

2. Introduce pure nitrogen at 1.3 atmosphere pressure and heat to $2000^{\circ} \mathrm{C}$.

3. Sinter in nitrogen for 1.5 hours at $2000^{\circ} \mathrm{C}$.

4. Cool to $1400^{\circ} \mathrm{C}$ and evacuate.

5. Cool to room temperature under vacuum.

Core compacts sintered in this manner were 76 to 78 percent of theoretical density. To further densify and strengthen these cores, they were canned in expendable molybdenum tubing and hot-gas isostatic pressed (autoclaved) at $1750^{\circ} \mathrm{C}$ under 10,000 psi pressure. This increased the density to $95 \%$ of theoretical for $W-60 u N$ and to $97 \%$ for Mo-60uN. The microstructures of such cores are shown in Figure 2.

After machining these core compacts to size for cladding they were cleaned by heating to $1400^{\circ} \mathrm{C}$ in vacuum. Tungsten and molybdenum alloy cladding components were similarly cleaned prior to assembly with the core. After sealing by $E B$ welding the fuel element specimen was hotgas pressure bonded at $1750^{\circ} \mathrm{C}$ under 10,000 psi helium pressure. Those specimens that were to be used in the thermal cyclic test program were subjected to a diffusion treatment at $2000^{\circ} \mathrm{C}$ for 6 hours to further enhance the core-to-cladding bond.

Thermal Stability Test Program

Several different evaluations of refractory metal-UN cermet fuel elements is in progress at GE-NSP. Long-time (10,000-hour) thermal stability testing of W-Re-clad W-UN fueled specimens is underway at $1800^{\circ} \mathrm{C}$ in helium and additional specimens will be placed on test at $1400^{\circ}$ and $1600^{\circ} \mathrm{C}$. The measurement of stability is the ability of a fuel specimen to remain leak-tight, well bonded, and free of microstructural defects or fuel interactions for as long as 10,000 hours. To date, the specimens on test at $1800^{\circ} \mathrm{C}$ show good stability after 1000 hours.

A second evaluation of UN cermet fuel elements is being performed in lithium environment for Space Power applications. This work originally initiated under the 710 Reactor Program will demonstrate the relative stability of clad $W-U N$ and $W-U_{2}$ fuel elements in a dynamic lithium Toop. Under NASA sponsorship single-channel specimens of W-60UN clad with $W$-Re-Mo alloy have been successfully proof-tested for 100 hours in static lithium at $2600^{\circ} \mathrm{F}$ and will be further tested in a dynamic lithium loop early in the coming year.

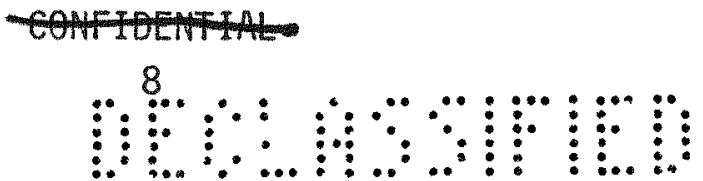




\section{आサய!}

CHTHTHIIL

A third area of Un fuel research is dimensional stability (qrowth) under thermal cyclic conditions. As discussed in the next section, the results of these growth studies of UN cermets in comparison with $\mathrm{UO}_{2}$ cermets are encouraqing enough that future in-plle tests will include W-UM fuel elements to be tested under conditions of high fission density.

Dimensional Stability Under Thermal Cyclic Conditions

A thermal cyclic test program is in progress at GE-NSP to determine the dimensional changes of refractory-metal-clad cermet fuel element specimens when thermal cycled rapidly between $300^{\circ}$ and $1800^{\circ} \mathrm{C}$. Cermet fuel cores containing uil as a nuclear fuel are being compared with $\mathrm{UO}_{2}-$ fueled cores with both $\|$ and Mo matrices.

All test specimens were solid cylinders, $1.27 \mathrm{~cm}$ in diameter with a nominal length of $2.8 \mathrm{~cm}$. All tunasten alloy cladding was $0.38 \mathrm{~mm}$ thick and the Mo and TZM alloy were $0.51 \mathrm{~mm}$ thick. The procedure used for the preparation of the fuel, sintered cores, and assembled specimens was the standard process described previously.

For thermal cyclic testing, the fully bonded specimens were contained in a $W$ or lio crucihle, depending on cladding material of specimens being tested. The test facility including the cammcontroller and hioh temperature resistance furnace is shown in Figure 3 . The specimens were cycled to $1800^{\circ} \mathrm{C}$ in high-purity helium atmosphore using the heatina and cooling rates of cycle $A$ shown in Ficure 4 , with a 5-minute dwell at $1800^{\circ} \mathrm{C}$. The testing is normally interrupted after $10,30,60$, and 100 cycles to record changes in diameter, length, volume, and weight. Each specimen is checked ultrasonically for claddino-to-core bond and for leaks in the cladding. Selected specimens are removed after 60 and 100 cycles for metallographic evaluations of cermet integrity.

The excellent visual appearance of clad fuel specimens typical of those exposed to 100 thermal cycles to $1800^{\circ} \mathrm{C}$ is shown in Figure 5 . A11 tunasten-alloy-clad specimens remained leak-free and well bonded as indicated by ultrasonic inspection.

The results of thermal cyclic testing $W-U 0_{2}, W-U N$ and Mo-UN cermet fuel specimens are given in Table 4. After 60 and 100 thermal cycles to $1800^{\circ} \mathrm{C}$ the diametral increases were greater for $\mathrm{H}-600 \mathrm{O}_{2}$ cermet cores than for $W-60 u N$ cermets tested under the same conditions. When Mo was substituted for the $1 /$ matrix material the arowth of the cores containing UN decreased even more. The addition of Re to the $I$ matrix to increase ductility, had an adverse effect on dimensional stability.

The thermal cyclic test data for diametral growth are summarized araphically in Figure 6, based on the average values for two or three specimens of one system. Data for those specimens which lost core-tocladding bond during test were not included in these average values. These data show that very little growth occurs durino the first 10 cycles for either un or $\mathrm{UO}_{2}$ fueled cermet cores. Exceptions to this 


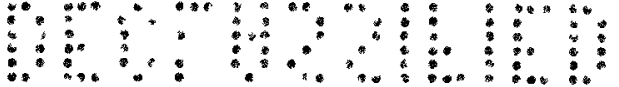

\section{CONFIUENTHE}

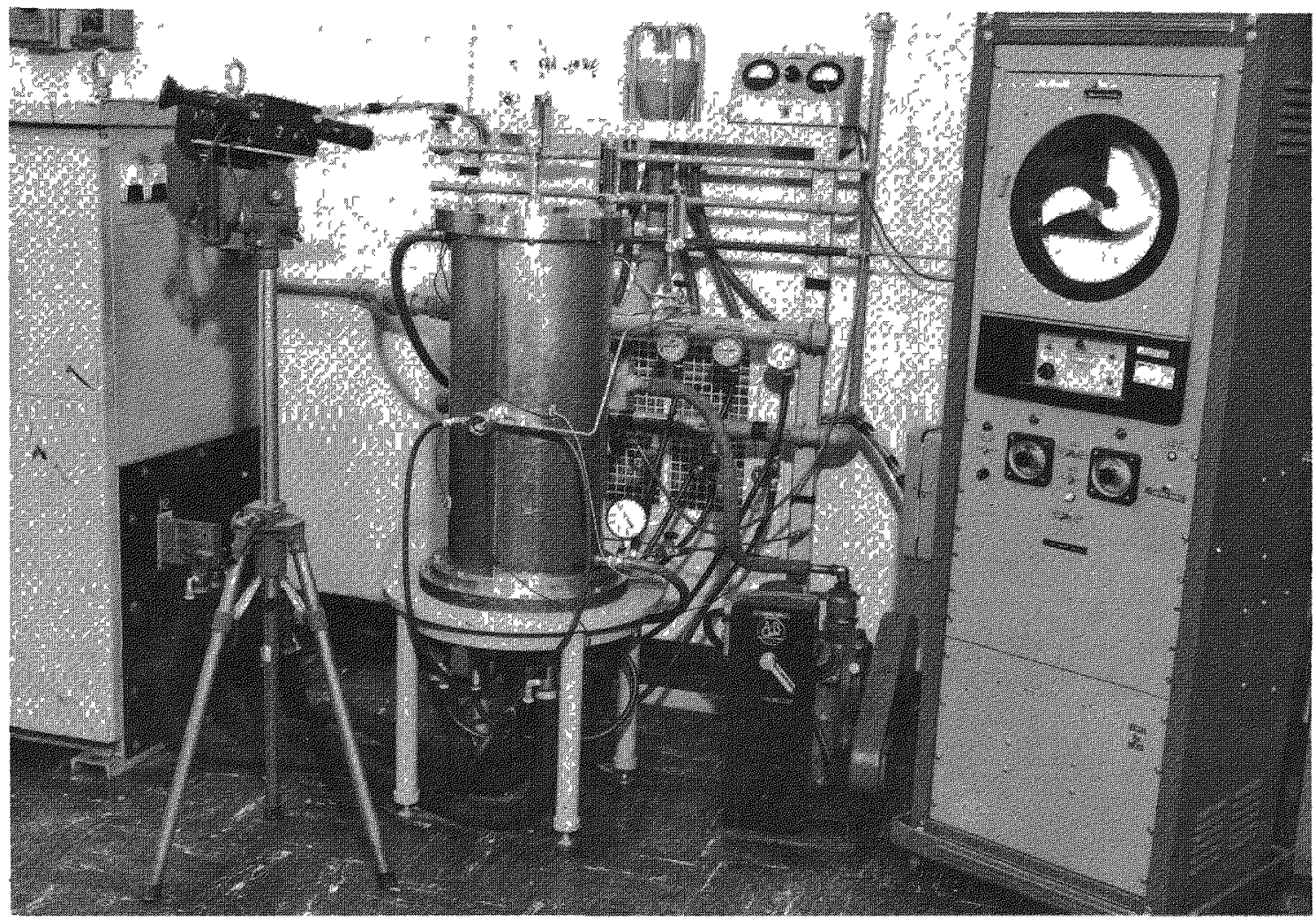

Fig. 3 - Thermal cyclic test facility used for dimensional stability studies. The water-cooled stainless steel furnace contains a $7.6-\mathrm{cm}$-diameter double-tube tungsten filament which can operate above $2600^{\circ} \mathrm{C}$ with vacuum or inert gas atmosphere. Controlled fast heating is accomplished by 125-KVA power input programmed by transducer control of saturable reactor. Continuous operation with dwell times up to 5 hours per cycle is possible through use of the automatic cam-programmed controller. Twenty fuel element specimens can be thermal cycle tested simultaneously. (Neg. P68-7-30)

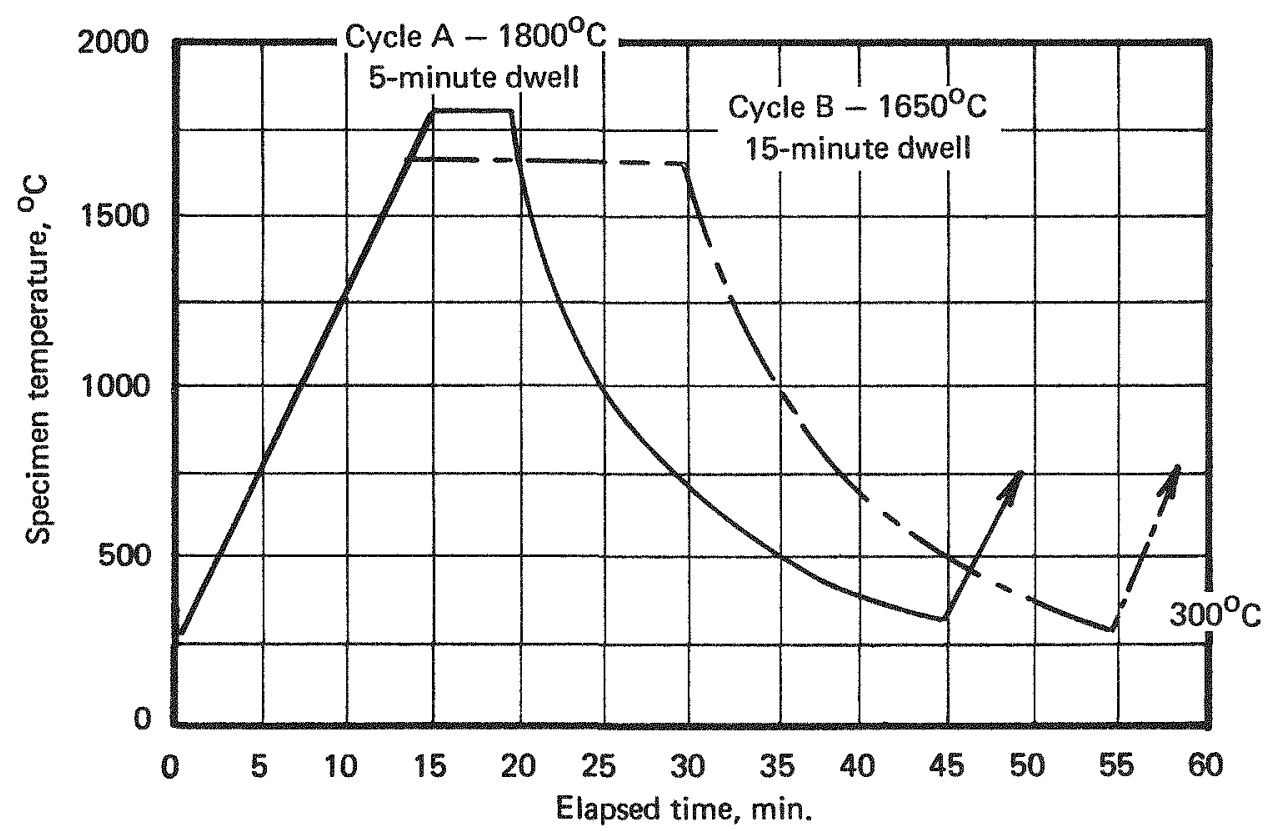

Fig. 4 - Heating and cooling curves of $1650^{\circ} \mathrm{C}$ and $1800^{\circ} \mathrm{C}$ thermal cycle test procedures used in dimensional stability study of cermet fuel cores
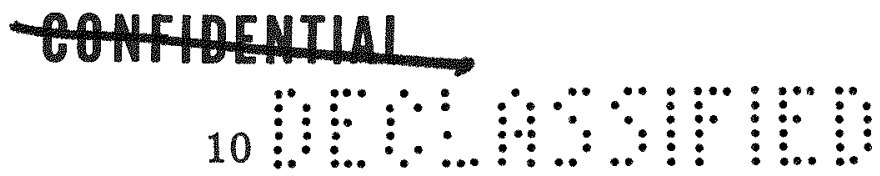


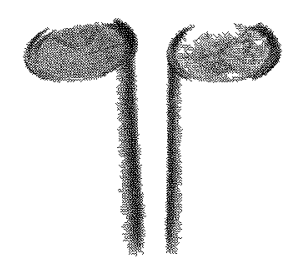

U-25Re-Clad W-5Re-60UN

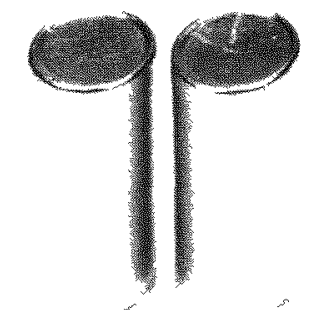

W-30Re-3010-Clad H.60UN

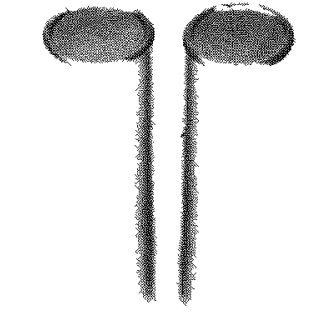

$4-25 R e-30 \% \%-C 7 a d$ M - 5Re-UO?

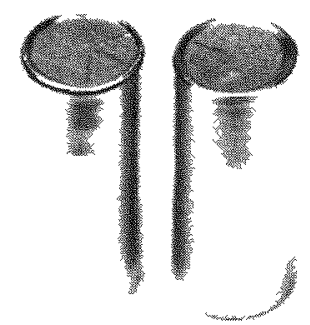

W-25pe-Clad y-60un

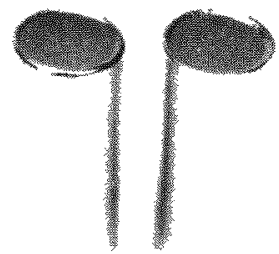

$1-30$ Re-30Mo-Clad N-5Re-60UN

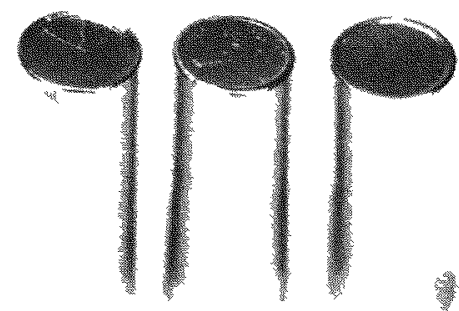

I-30Re-30mo-clad U-3Re-60UN
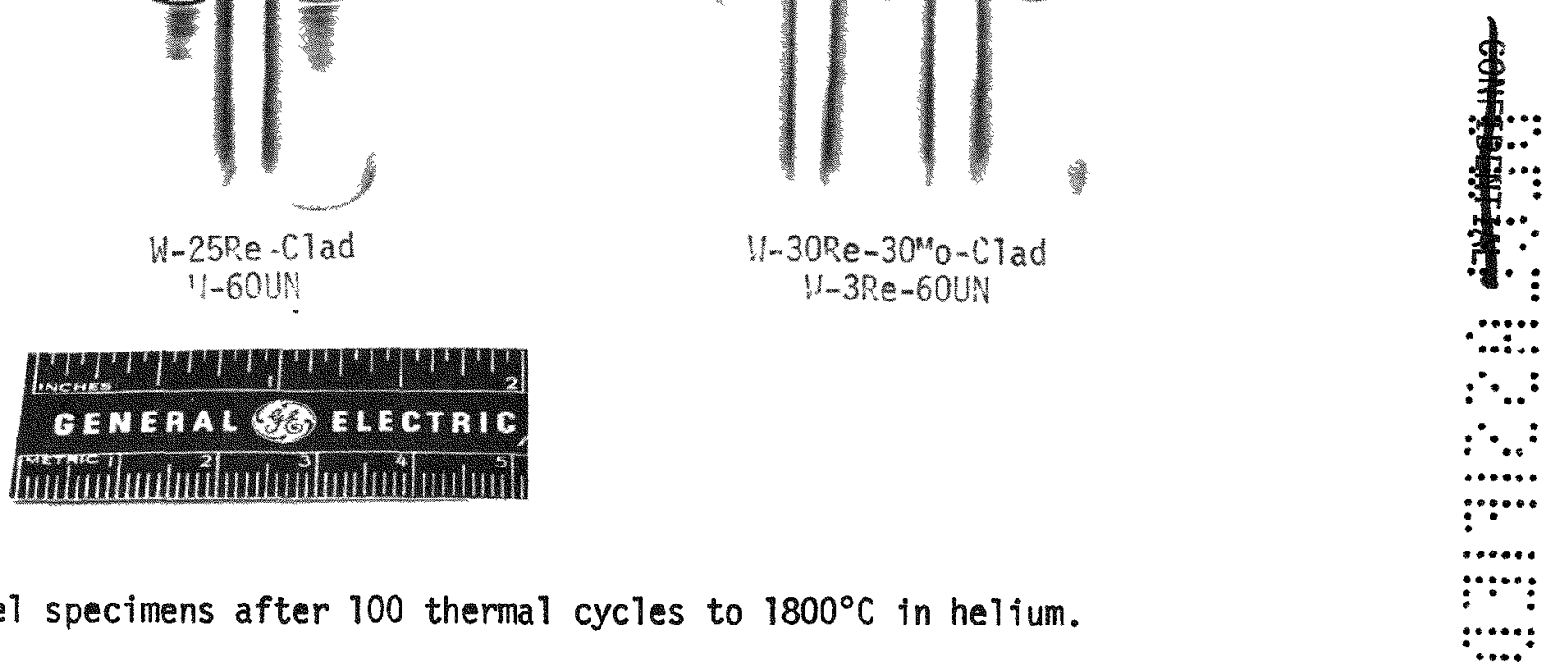

Figure 5 - Typical clad cermet fuel specimens after 100 thermal cycles to $1800^{\circ} \mathrm{C}$ in helium. (Neg. 68-8-16A) 
TABLE 4

CHANGES IN REFRACTORY METAL CERMET FUEL ELEMENTS UPON RAPID THERMAL CYCLIC TESTING TO $1800^{\circ} \mathrm{C}^{2}$

\begin{tabular}{|c|c|c|c|c|c|c|c|c|c|c|c|c|c|c|}
\hline \multirow{2}{*}{$\begin{array}{l}\text { Core } \\
\text { Composition, } \\
\text { vol \% } \\
\end{array}$} & \multirow{2}{*}{$\begin{array}{l}\text { Cladding } \\
\text { Composition, } \\
\text { at. } \%\end{array}$} & \multicolumn{4}{|c|}{$\begin{array}{l}\text { Diametral Change } \\
\text { After Indicated } \\
\text { Number of Cycles, } \%\end{array}$} & \multicolumn{4}{|c|}{$\begin{array}{l}\text { Length Change } \\
\text { After Indicated } \\
\text { Number of Cycles, } \%\end{array}$} & \multicolumn{4}{|c|}{$\begin{array}{l}\text { Volume Change } \\
\text { After Indicated } \\
\text { Number of Cycles, } \%\end{array}$} & \multirow{2}{*}{$\begin{array}{c}\text { Spec. } \\
\text { No. }\end{array}$} \\
\hline & & 10 & 30 & 60 & 100 & 10 & 30 & 60 & 100 & 10 & 30 & 60 & 100 & \\
\hline W- $50 \mathrm{UN}$ & w -30 Re-30Mo & 0.04 & $0.30^{\mathrm{d}}$ & 0.84 & 1.36 & 0.19 & 0.50 & 1.08 & 1.54 & 0.29 & 1.31 & 2.78 & 3.77 & $274-1$ \\
\hline $\mathrm{W}-60 \mathrm{UN}$ & W-30Re-30Mo & 0.03 & 0.01 & 0.28 & 0.97 & 0.16 & 0.67 & 1.46 & 1.22 & 0.21 & 1.08 & 2.62 & 4.59 & $274-2$ \\
\hline$W-60 U N$ & W-3ORe-30Ro & 0.04 & 0.02 & 0.27 & $c$ & 0.18 & 0.57 & 1.37 & $c$ & 0.18 & 1.06 & 2.50 & c & $274-3$ \\
\hline$w-600 N$ & h-25Re & 0.14 & $0.62^{d}$ & 1.04 & 1.14 & 0.18 & 0.42 & 0.71 & 1.09 & 0.51 & 1.60 & 2.72 & 3.33 & $274-5$ \\
\hline$W-60 U N$ & W-25Re & 0.05 & 0.43 & 1.17 & 1.79 & 0.23 & 0.61 & 0.85 & 2.33 & 0.45 & 1.66 & 3.41 & 4.83 & $274-6$ \\
\hline$w-60 \mathrm{UO}_{2}$ & W-25Re-30No & -0.04 & $0.12^{\mathrm{d}}$ & $\mathrm{c}$ & $\mathrm{c}$ & 0.04 & 0.50 & $\mathrm{c}$ & $c$ & 0.16 & 1.26 & $\mathrm{c}$ & $c$ & $270-1$ \\
\hline $\mathrm{W}-60 \mathrm{UO}_{2}$ & W-25Re-30MO & -0.02 & 0.10 & 1.13 & $2.93^{d}$ & 0.03 & 0.47 & 2.03 & 3.47 & 0.14 & 1.22 & 3.37 & 6.83 & $270-3$ \\
\hline$W-60 v o_{2}$ & $W-25 R e-30 \mathrm{Mo}$ & -0.02 & 0.04 & $1.13^{d}$ & 3.21 & 0.03 & 0.42 & 2.08 & 3.67 & 0.12 & 1.14 & 4.02 & 7.35 & $270-5$ \\
\hline$(W-3 R e)-60 U N$ & w-30\%e-30Mo & 0.04 & 0.09 & 0.43 & 1.22 & 0.01 & 0.47 & 1.30 & 2.14 & 0.26 & 1.03 & 2.66 & 4.21 & $276-1$ \\
\hline$(W-3 R e)-60$ UN & $W-30 R e-30 \mathrm{WO}$ & 0.02 & 9.08 & 0.37 & $\mathrm{c}$ & 0.11 & 0.49 & 1.31 & $\mathrm{c}$ & 0.23 & 1.05 & 2.80 & $c$ & $276-2$ \\
\hline$(N-3 R e)-60 U N$ & $W=30 \mathrm{Re}-30 \mathrm{MO}$ & $M 11$ & 0.10 & 0.55 & 1.42 & 0.13 & 0.55 & 1.33 & 2.09 & 0.27 & 1.17 & 2.81 & 5.12 & $276-3$ \\
\hline$(W-3 R e)-60 \mathrm{UO}_{2}$ & $W-25 R e-30 M o$ & 0.54 & 0.56 & 1.27 & 2.64 & 0.42 & 0.96 & 1.26 & 2.63 & 1.56 & 1.83 & 4.07 & 8.02 & $278-1$ \\
\hline$(W-3 R e)-6010_{2}^{4}$ & $W-25 R e-30 M O$ & 0.47 & 0.76 & 1.63 & e & 0.39 & 0.71 & 1.49 & $e$ & 1.35 & 2.24 & 4.51 & $e$ & $278-3$ \\
\hline$(\mathrm{W}-3 \mathrm{Re})-60 \mathrm{VO}_{2}$ & W -25 Re -30 ho & 0.57 & 0.62 & 1.32 & 2.70 & 0.44 & 0.62 & 1.33 & 2.70 & 1.58 & 1.92 & 4.17 & 8.19 & $278-4$ \\
\hline$(W-5 R e)-60 U N$ & W-25Re & 0.04 & 0.26 & 1.06 & $c$ & 0.13 & 0.57 & 1.32 & $c$ & 0.40 & 1.56 & 3.54 & $\mathrm{c}$ & $277-4$ \\
\hline$(W-5 R e)-60 U N$ & $W-25 R e$ & 0.02 & 0.24 & 1.02 & 1.87 & 0.13 & 0.54 & 1.39 & 1.84 & 0.33 & 1.46 & 3.52 & 5.53 & $277-5$ \\
\hline$(W-5 R e)-60 U N$ & W-25Re & 0.02 & 0.32 & 0.75 & 1.71 & 0.10 & 0.55 & 1.47 & 3.92 & 0.29 & 1.28 & 3.34 & 5.40 & $277-6$ \\
\hline$(W-5 R e)-60 U N$ & $W-30$ Re -30 Mo & 0.02 & 0.15 & 0.66 & 1.52 & 0.10 & 0.48 & 1.27 & 2.01 & 0.59 & 1.07 & 2.90 & 5.19 & $277-1$ \\
\hline$(N-5 \operatorname{Re})-60 U N$ & WoRe-30Mo & 0.02 & 0.15 & 0.67 & 1.42 & 0.11 & 0.50 & 1.27 & 1. .95 & 0.31 & 1.19 & 2.97 & 2.70 & $277-2$ \\
\hline$(W-5 R e)-60 U N$ & W-30Re-30Mo & 0.02 & 0.18 & 0.70 & c & 0.15 & 0.56 & 1.42 & $\mathrm{c}$ & 0.27 & 1.29 & 3.18 & $\mathrm{c}$ & $277-3$ \\
\hline$(\mathrm{W}-5 \mathrm{Re})-6 \mathrm{OUO}_{2}$ & W $-25 \mathrm{Re}-30 \mathrm{MO}$ & 0.32 & 0.69 & 1.43 & 2.41 & 0.20 & 0.52 & 1.35 & 2.18 & 0.73 & 1.82 & 4.10 & 6.96 & $278-25$ \\
\hline$(W-5$ Re $)-6000_{2}$ & $W-25 R e-30 M$ & 0.35 & 0.71 & 1.42 & 2.32 & 0.19 & 0.55 & 1.29 & 2.07 & 0.71 & 1.85 & 3.93 & 6.42 & $278-26$ \\
\hline$(W-5 R e)-60 U O_{2}$ & $W-25 R e-30 M o$ & 0.29 & 0.68 & 1.44 & $\mathrm{c}$ & 0.19 & 0.54 & 1.32 & $\mathrm{c}$ & 0.04 & 1.23 & 3.49 & c & $278-27$ \\
\hline Mo-60UN & 100Mo & 0.04 & 0.28 & $0.54^{f}$ & 0.98 & 0.04 & 0.12 & 0.36 & 0.56 & 0.19 & 0.51 & 1.23 & 1.79 & $279-2$ \\
\hline Mo-60uN & 100 Mo & 0.04 & 0.22 & $0.54 \mathrm{f}$ & 0.92 & 0.03 & 0.17 & 0.37 & 0.58 & 0.11 & 0.43 & 1.08 & 1.59 & $279-3$ \\
\hline Mo- $60 \mathrm{UN}$ & $100 \mathrm{Mo}$ & 0.08 & 0.29 & $0.44^{f}$ & $c$ & 0.10 & 0.79 & 0.81 & $\mathrm{c}$ & 0.19 & 0.65 & 1.42 & $c$ & $279-7 \mathrm{C}$ \\
\hline Mo $-60 \mathrm{UN}$ & $\mathrm{Mo}-0.5 \mathrm{Tz}-0.08 \mathrm{Zr}$ & 0.06 & 0.24 & $0.46^{\mathrm{f}}$ & 0.81 & -0.03 & 0.07 & 0.25 & 0.50 & 0.17 & 0.46 & 1.10 & 1.64 & $279-8 b$ \\
\hline Mo-60UN & $M O=0.5 T x-0.08 Z r$ & 0.04 & 0.18 & $0.40^{f}$ & 0.75 & -0.03 & 0.15 & 0.37 & 0.59 & 0.24 & 0.50 & 1.12 & 1.54 & $279-10$ \\
\hline
\end{tabular}

$300^{\circ}$ to $1800^{\circ} \mathrm{C}$ in $15 \mathrm{~mm}, 5 \mathrm{~min}$ dwell and cool to $300^{\circ} \mathrm{C}$ in $25 \mathrm{mun}$.

$b_{\text {A11 }}$ changes are increases unless otherwise noted.

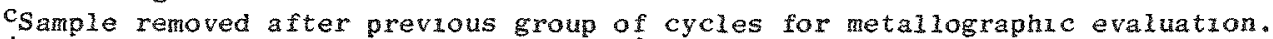

dultrasonic indications of poor bond. Leak in cladding detect on 60 cycle inspection.

eIn progress. 
H:

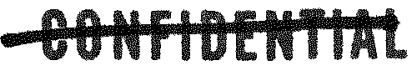

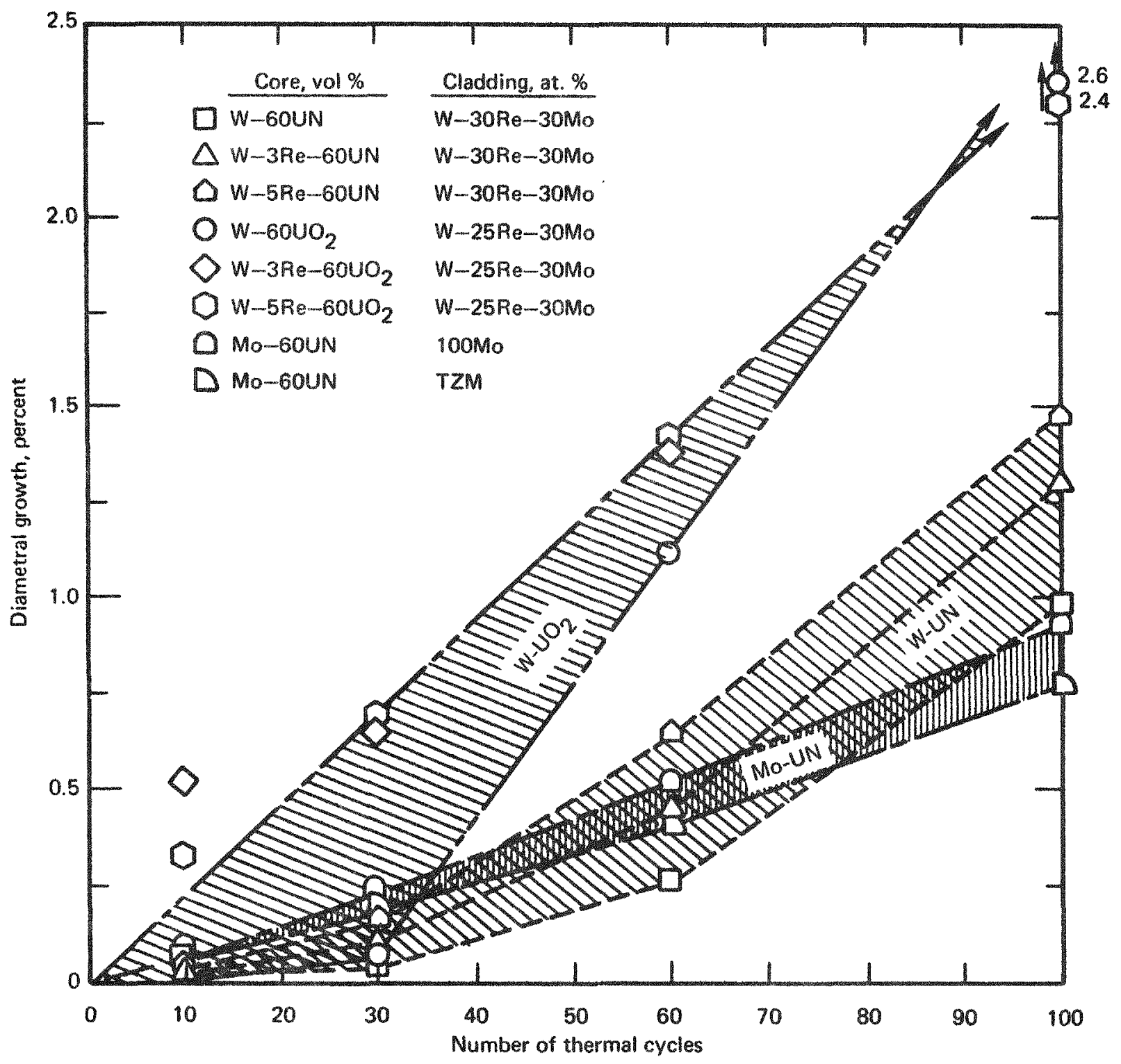

Diametral growth of cermet fuel cores containing $\mathrm{UO}_{2}$ or UN as a function of number of thermal cycles to $1800^{\circ} \mathrm{C}$

Figure 6 


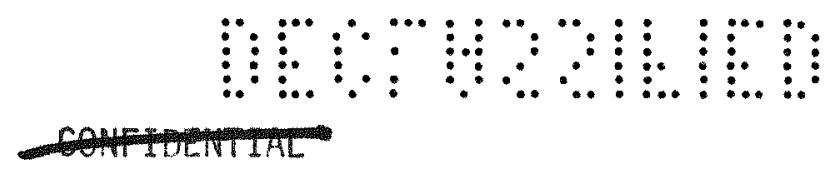

were shown by $\mathrm{UO}_{2}$ fuel cores with 3 to 5 percent Re additions to the $W$ matrix. The average growth rate did not increase appreciably between 10 and 30 cycles but was accelerated in going to 60 and 100 cycles.

It should be noted that these test conditions of rapid thermal cyclino with short hold time at $1800^{\circ} \mathrm{C}$ imposes more severe conditions than would be experienced in an operating reactor where longer hold times at temperature would be expected to relieve some of the stresses resultine from rapid cooling. Furthermore, an operating reactor would not normally be cycled more than 60 times and based on these data the diametral growth would not exceed 1 percent for either $4-60 u N$ or Mo-60uN cermet cores.

Not shown in the graphical presentation of Figure 6 are growth data for five specimens of $W$-UN and W-Re-Un which were clad with W-25Re alloy. The growth rates of these specimens were greater than similar cermet cores clad with W-Re-Mo alloys. Metallographic examination of these specimens revealed considerable porosity developed in the $\mathrm{H}-25 \mathrm{Re}$ alloy cladding after 60 and 100 cycles with increase in thickness of 2 to 3 mils $(13 \%)$. This porosity and increase in cladding thickness is attributed to impurities in the as-fabricated tubino and possibly precipitation of Re-rich sigma phase during thermal cycling. No evidence of incompatibility with UN fuel was found.

Metallographic examination was performed for about half the specimens that were subjected to 100 cycles and for selected specimens after 60 cycles. These were compared to the microstructures of specimens in the pre-test condition (after $2000^{\circ} \mathrm{C}-6$ hour treatment).

The microstructures of a series of W-Re-Mo clad W-60UN specimens are shown in Figure 7 in three stages of testing. In the pre-test condition the 306 alloy cladding was single phase and well bonded to the core matrix but with scattered voids at the interface; the UN fuel particles contained both $\mathrm{UH}_{\mathrm{X}}$ and $\mathrm{UO}_{2}$ phases but no free $U$; the $W$ matrix was in intimate contact with the un fuel particles.

After 60 cycles to $1800^{\circ} \mathrm{C}$ the $W$-30Re-30Mo cladding developed intergranular porosity and voids at the inside surface; separation of core and cladding was evident in some areas and porosity developed in the $W$ matrix and around the fuel particles; increased $\mathrm{U}_{2}$ phases were evident in the UN but no free $U$ was observed. The UII fuel particles were extensively cracked as a result of thermal cycling and this cracking is in proportion to the volumetric growth of 2.5 percent shown by this specimen.

After 100 cycles the microstructural damage was similar to that of the 60 cycle specimen but was accentuated in proportion to the additional number of cycles and the increased growth $(3.7$ vol.\%).

For combarison the microstructure of a W-25Re-30Mo-clad $W-6010_{2}$ specimen (0270-5) is shown in Figure 8 after 100 thermal cycles. The volume increase of this specimen was measured as 7.35 percent. The 256 alloy cladding developed intergranular porosity similar to that 
of the W-UN specimen discussed above but the porosity was more extensive, forming large voids in the grain boundaries in proportion to the increased growth of $\mathrm{H}-\mathrm{UO}_{2}$ cermet. This porosity of the cladding has been observed previously in test specimens clad with this lot of 256 alloy tubing and is attributed to impurities in the cladding alloy; it does not appear to be related to fuels incompatibility for either UN or $\mathrm{UO}_{2}$. Metallographic evaluation of the $\mathrm{W}-\mathrm{UO}_{2}$ cermet was made difficult by the excessive pull-out of fuel particles and matrix materials that were no longer locked in place after the volumetric expansion of the cermet. The greater microstructural damage to both the core and cladding of the $\mathrm{W}-\mathrm{UO}_{2}$ as compared to $\mathrm{W}-U \mathrm{~N}$ is attributed to the higher coefficient of thermal expansion of $\mathrm{UO}_{2}(10.58$ vs .8 .61 $\times 10^{-6}$ per $\left.{ }^{\circ} \mathrm{C}\right)$.

A11 Mo-clad Mo-60uN specimens developed leaks in the grain boundaries of the cladding between 30 and 60 cycles. Typical of this type of leak is the claddina defect shown in the photomicrograph of Finure 9 . This TZM-clad Mo-60ul specimen was subjected to 100 cycles although a leak was detected during the 60 -cycle inspection. As a result of this leak, increase in the $\mathrm{UO}_{2}$ and $\mathrm{UN}_{\mathrm{X}}$ phases occurred in the UN fuel particles. Apparently the UN fuel remains stable as long as it is totally contained within the cladding, but is readily converted by impurities in the helium atmosphere as soon as a cladding leak occurs. The lesser amount of crackinc shown by both fuel and core in this MO-UN cermet is related to the lower volumetric growth $(1.54$ vol.\%) measured for this specimen.

Selected specimens of each system were subjected to an isothermal soaking treatment at $1800^{\circ} \mathrm{C}$ to determine if any healing of the core or recovery of the dimensional growth might occur. These specimens had diametral growth of 1 to 2 percent after 100 cycles to $1800^{\circ} \mathrm{C}$. After 500 hours at $1800^{\circ} \mathrm{C}$ in helium considerable shrinkage was measured, and after 1000 hours small additional shrinkage occurred as shown by the data in Table 5. The specimen containing $\mathrm{UO}_{2}$ recovered more rapidly than those containing UN fuel.

One specimen (274-2) which had a cladding leak after 500 hours was examined metallooraphicaliy to determine the mechanism of the shrinkage upon thermal soaking. The microstructural damage appeared little different from the condition after 100 thermal cycles with porosity at the interface and in the $W$ matrix. No evidence of fuel incompatibility or instability was observed although $\mathrm{UO}_{2}$ was detected in the UN fuel particles, especially at the core - cladding interface, and probably resulted from the cladding leak. The only evidence of shrinkage having occurred was a coalescence of fine porosity to form larger voids adjacent to the fuel particles.

The isothermal soaking of these specimens is being continued at $1800^{\circ} \mathrm{C}$ in helium with periodic examination for dimensional and thermal stability.

Uranium mononitride offers several distinct advantages over $\mathrm{UO}_{2}$ as a fuel dispersion in refractory metal cermets. Higher specific uranium 

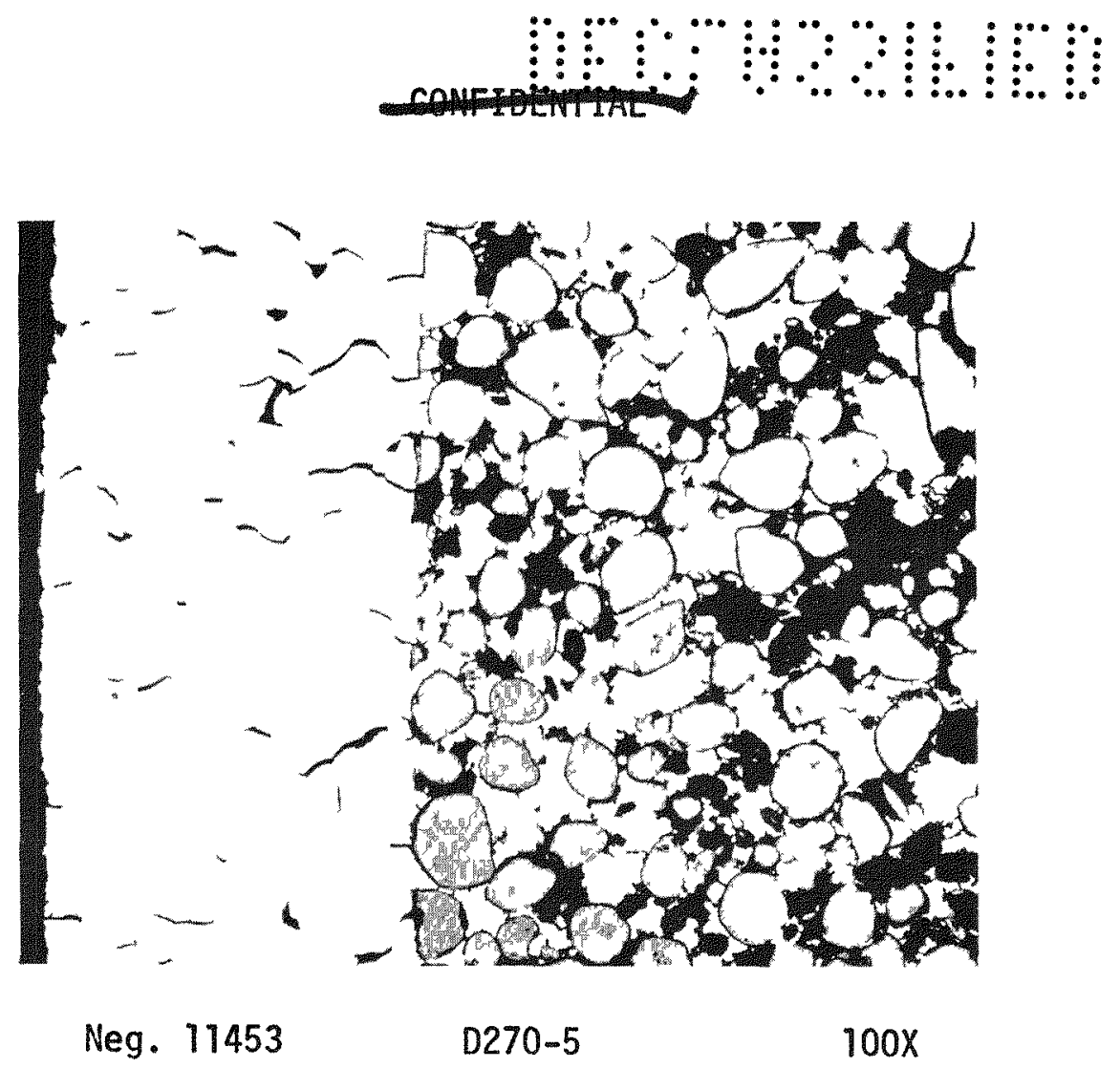

Figure 8 - Microstructure of W-25Re-30MO-Clad W-60UO 2 after 100 cycles to $1800^{\circ} \mathrm{C}$ with diametral growth of 3.21 percent.

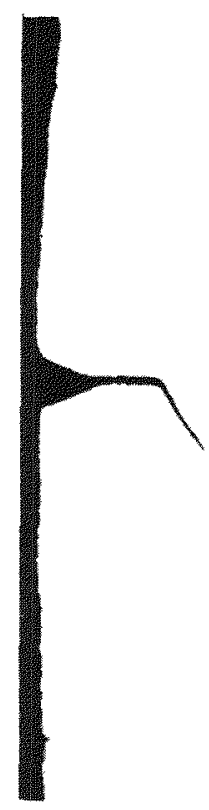

Neg. 11286

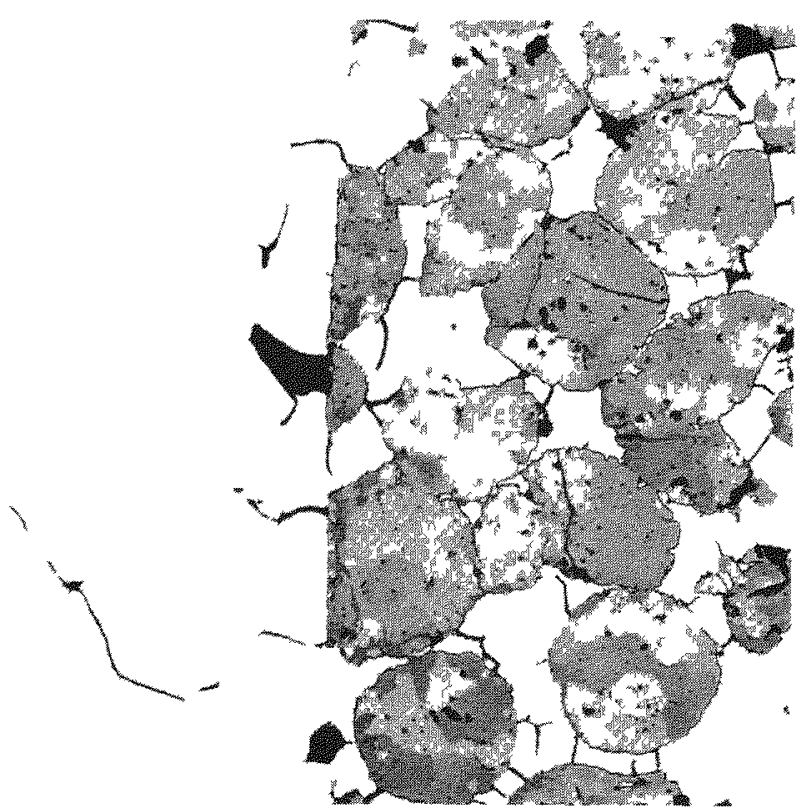

D279-10
$100 x$

Figure 9 - Microstructure of TZM-clad MO-60UN after 100 cycles to $1800^{\circ} \mathrm{C}$ with diametral growth of 0.75 percent. 
TABLE 5

EFFECT OF ISOTHERMAL TREATMENT AT $1800^{\circ} \mathrm{C}$ ON DIAMETRAL GROWTH

OF U-UN SPECIMENS AFTER THEPMAL CYCLIC TESTING

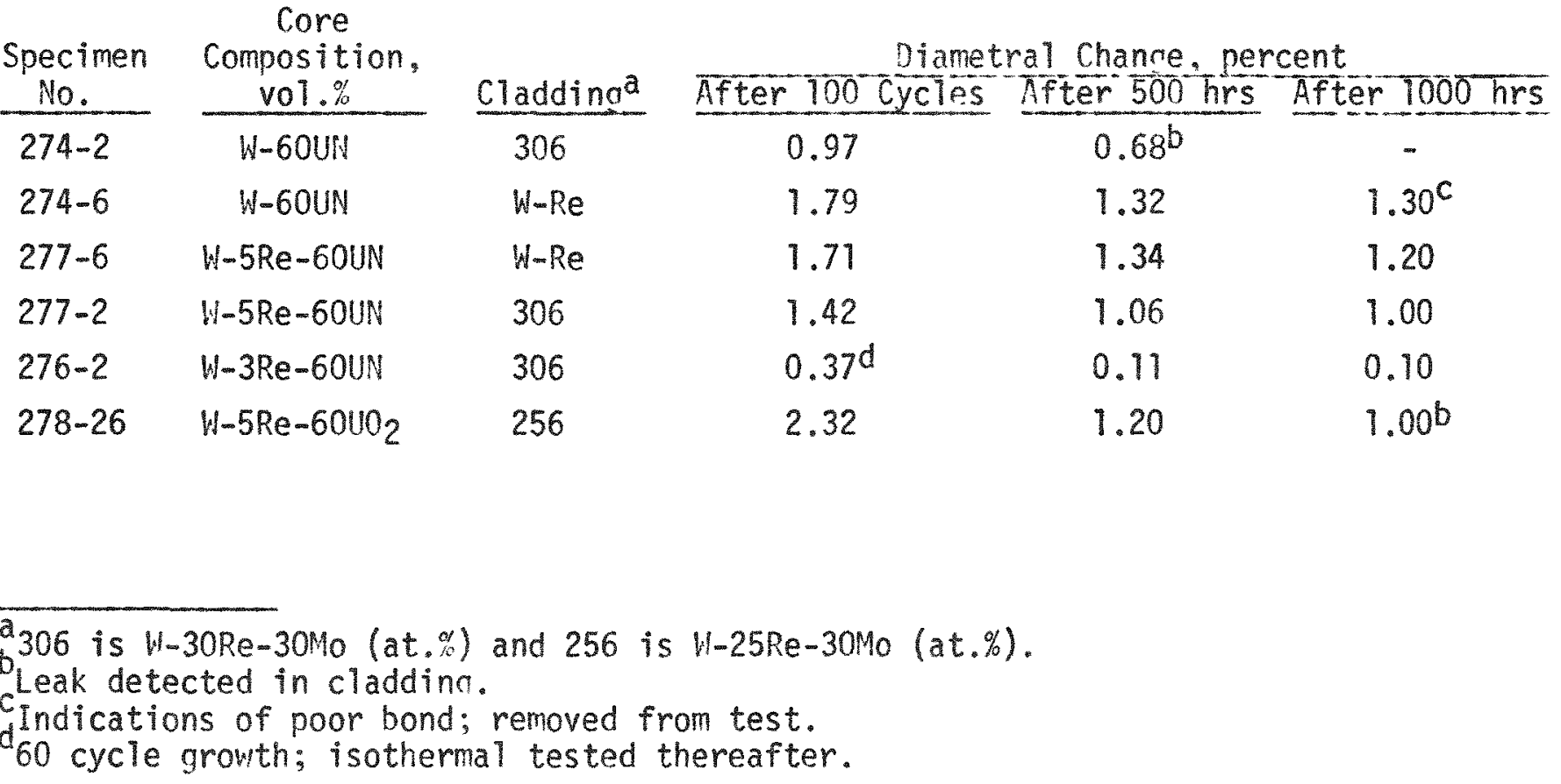


content, higher thermal conductivity, and lower thermal expansion are among these advantages but most important is the improved dimensional stability or resistance to growth under thermal cyclic conditions.

An important factor in the improved dimensional stability of W-UN cermets is the development of a process for preparing high-purity, spherical UN particles by direct nitriding of uranium metal shot. Fuel particles in the size range of 100 to 150 microns can be produced of near stoichiometric composition with oxygen contents of 500 to $800 \mathrm{ppm}$; furthermore, this fuel can be processed like $\mathrm{UO}_{2}$ without need for protective atmosphere. The possible limitations to this method of producing UP lie in the availability of enriched metal shot and of the finer particle sizes desired for cermet fuel cores.

The UN fuel particles maintain compositional stability when sintered or heat treated in nitrogen under positive pressure above $1400^{\circ} \mathrm{C}$, but with all treatment below $1400^{\circ} \mathrm{C}$ in vacuum. Once encapsulated in a gastight cladding the UN fuel has excellent thermal stability.

Results of a series of thermal cyclic tests of clad $1-60 u N$ and Mo-60uN specimens in comparison with similar specimens fueled with $\mathrm{UO}_{2}$ indicate that in 60 rapid cycles to $1800^{\circ} \mathrm{C}$ the un cermet cores grow less than 0.5 percent in diameter versus 1.1 percent minimum growth for $\mathrm{U}_{2}$ cermets tested under the same conditions (Figure 6). The difference is even greater after 100 thermal cycles. These tests are also conducted under conditions of much greater severity than would be imposed on an operating reactor or thermionic emitter system.

The dimensional growth of the $W$-UN cermet was reflected in the microstructures of the specimens after 60 and 100 thermal cycles. The UN fuel particles were cracked, porosity developed in the tungsten matrix and around fuel particles, and separation of core and claddino occurred in some areas. This type of core damage is common to all thermal cycle test specimens which show some growth and does not reflect fuels instability or incompatibility. The only evidence of UN instability occurred in those specimens clad with molybdenum which leaked, permitting the admission of oxygen and the formation of $\mathrm{UO}_{2}$. It was not determined what effect small amounts of $\mathrm{UO}_{2}$ would have on the performance of $W$-UN cermet fuel cores.

IVEED FOR FURTHER DEVELOPMENT WORK

The data presented herein should be treated as preliminary evaluations, but nonetheless of considerable significance in showing the potential of UN cermet fuels as well as highlighting the need for further studies and development of UN as an alternate fuel. It is recommended that to qualify UN cermets for in-pile testing on the same basis as has been established for $\mathrm{UO}_{2}$, a five part development program should be conducted.

1. In the area of fuel development, the current preparation technique for UN should be defined with an understanding of the chemistry at each step to better control purity and stoichiometry; efforts to produce UN of smaller particle size from metal shot should be made; also a fuel particle of lower density is needed for better sinter-

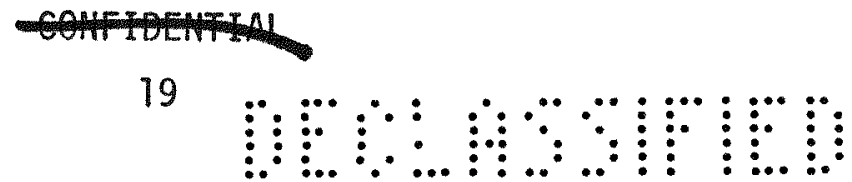




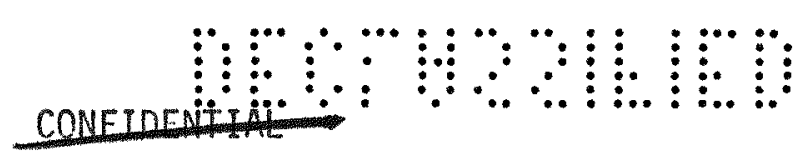

ability and with built in porosity for fission qas retention: a better understandina of the uranium-nitrogen system would be helpful in determining thermal stability and compatibility of each of the phases in the fuel system; and finally the coatinn of optimum UN particles with tungsten and molybdenum by the chemical vapor deposition method should be developed as a reliable process that will not affect the stoichiometry of the Un fuel.

2. In the area of fueled core development the cermet of maximum fuel loading (75-80 v01.\% UN) should be determined as well as the blending technique to obtain a dispersion comparable to coated fuel cores; sintering techniques for Mo-UN and W-UN cermets should be refined to produce a fuel core of higher density with controlled stoichiometry of the un fuel.

3. Cladding materials for W-UN and 110-UN cermet cores which are suit-able emitter materials should be evaluated for fabricability and long-time thermal stability and compatibility with fuels; the ability to maintain a core-to-cladding bond should be established for cladding materials such as CVD tungsten, W-25Re, Re, Mo, TZM and composites of these materials.

4. The dimensional stability of clad W-75UN and MO-75UN cermet cores should be established under both isothermal and thermal cyclic conditions at temperature of $1600^{\circ}$ to $1800^{\circ} \mathrm{C}$; a more realistic, less severe test cycle should be used with longer holdind time at temperature to determine effects on growth rates; testing should be conducted in vacuum as well as helium to determine the effect of atmosphere on growth as well as fuel stability in the event of a leak through the cladding; and the benefits of long-time heat treatment above the test temperature for reducing growth should be investigated.

5. Depending on favorable results from the current lithium loop test of single channel $W$-UN fuel specimens, further studies should be made of the stability of un in dynamic lithium using cermet fuel specimens with known defects in the cladding to determine the extent of the fuel-1ithium reaction.

6. The irradiation stability of un cermets should be determined through a series of in-pile tests using specimens of various core materials and fuel densities; the effectiveness of porous fuel particles and cermets of high void fraction in retention of fission gas products should be demonstrated to the same hich burnup levels that have been accomplished by $\mathrm{W}-\mathrm{UO}_{2}$ cermet fuels in the past. 


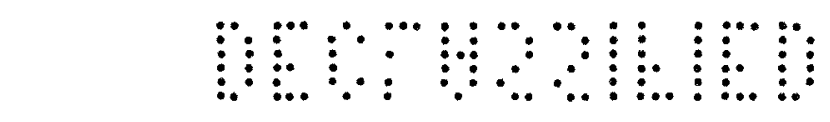

CONTLTHTIL

\section{REFERENCES}

1. Bugl, J., and Keller, D. L., "Uranium Mononitride - A New Fuel", Nucleonics, Vol. 22, No. 9, 1964, pp. 67-70.

2. "Nuclear Rocket Program Quarterly Progress Report Second Quarter 1965", ANL-7080, JuTy 1965.

3. "Nuclear Rocket Program Quarterly Progress Report Fourth Quarter $1965^{\prime \prime}$, ANL-7150.

4. Paprocki, S. J., Keller, D. L., et al., "Preparation and Properties of $\mathrm{UO}_{2}$ Cermet Fueis", BMI-1487, Dec. 1960.

5. Endebrock, R. W. (Ed.), "Properties of Fuels for High Temperature Reactor Concepts", BMI-1598, Nov. 1962.

6. Kempter, C. P. and Elliott, R. O., "Thermal Expansion of UN, $\mathrm{UO}_{2}$, $\mathrm{UO}_{2}-\mathrm{ThO}_{2}$, and $\mathrm{ThO}_{2}, " \mathrm{~J}$. Chem. Phy., Vol. 30, No. 6, June 1959, p. 1524 .

7. "Sixth Annual Report - High Temperature Materials Program, Part $A$ ", GE-IMPO, GEMP-475A, March 1967.

8. Dayton, R. W. and Dickerson, R.F., "Progress Relating to Civilian Applications During July 1962", BMI-1589.

9. "Thermal Conductivity and Electrical Resistivity of UN", FWAC-481, October 1965.

10. Dayton, R. K.. and Tipton, C. R., Jr., "Progress Relating to Civilian Applications during May 1961", BMI-1518.

11. Dayton, R. W. and Tipton, C.R., Jr., "Progress Relating to Civilian Applications during August 1961", BMI-1541.

12. Speidel, E. O. and Keller, D. L., "Fabrication and Properties of Hot Pressed UN", BMI-1633, May 1963.

13. Dayton, R. W. and Dickerson, R. F., "Proaress Relating to Civilian Applications During April 1962", BMI-1577.

14. Nelson, P. A. and Chasanon, M. G., "Nuclear Reactor Fuel Material and a Method for Preparing Same", USAEC Patent 3287093, 1966.

15. "Sixth Annual Report - High Temperature Materials Program, Part B", GE-NMPO, GEMP-475B, Feb. 1967, p. 72.

16. Feith, A. D., "Thermal Conductivity of Alumina, Thoria, and Tungsten", GESP-26, June 1968.

17. Feith, A. D. "Measurement of the Thermal Conductivity and Electrical Resistivity of Molybdenum", 1965 Conference on Thermal Conductivity, Denver, Colorado, GETM 65-10-1, Oct. 1965. 